\title{
Water in the City and Remote Sensing
}

\section{Lucia Tátošová, Karol Šinka, Beáta Novotná*, Dušan Húska}

Faculty of Horticulture and Landscape Engineering, Slovak University of Agriculture, Trieda Andreja Hlinku 2, 94976 Nitra, Slovak Republic

Received: 3 March 2021

Accepted: 1 December 2021

Published online: 30 December 2021

\begin{abstract}
At present, climate change is particularly evident in areas heavily used by man. Such localities are mainly urbanized areas. With the increment in urban area and construction related to urban development, the hydrological regime of such sites is disrupted. When the natural character of the surface has changed, where precipitation, evapotranspiration and outflow of water from the area has been balanced, there is now an increase in territories that are impermeable and caused almost $100 \%$ runoff. The influence of the built-up area on the temperature increase in urbanized areas in comparison with the surrounding landscape is also known as a thermal island. The identification of the current status and possible potential interventions in the water regime of cities is provided by the possibility of using information obtained from the satellite monitoring of the Earth's surface. The range of areas in urbanized areas contributing to runoff can be ascertained by remote sensing, where in particular using multispectral images, where it is possible to distinguish surface characteristics using LAI and controlled image classification. At the same time, it is possible to identify areas that could be used to create space for rainwater infiltration and its accumulation below the surface. The paper evaluates the extent of changes in land use in Nitra from 1954 to 2017. The growth of areas with minimal infiltration capacity in the area of the Slovak University of Agriculture is identified. Possibilities of use of rainwater and their accumulation in the monitored area are analyzed.
\end{abstract}

Keywords: remote sensing; urbanized area; LAI; water management; accumulation

\section{Introduction}

Water is an example of the renewability of our Earth's natural resources. It is the result of a constant circulation of water in nature, which is represented a hydrological cycle consisting of small and large water circulation (Antal and Igaz 2018). Within this cycle, the precipitation is an essential source of all land-based water, including those that originated in ancient geological times and constitute water supply in the deep horizons of the Earth's crust. At present, resources for restoring equilibrium in water supplies is only rainfall, which in present is subject to a phenomenon climate change (STN EN 16941-1 2018). Its impact is caused mainly by the increase in extreme events, which are tidal rains and, in particular, the uneven distribution of precipitation over the year. Thus, floods and erosion causing

\footnotetext{
* Corresponding author: Beáta Novotná

e-mail: beata.novotna@uniag.sk
} 
downpours come at different times, followed by droughts when water is scarce. In the context of climate change now, we will continue to face similar challenges. The situation caused by a new phenomenon due to dry years when there is a minimal influx of surface water from precipitation and a significant source of overheating occurs in built-up areas (Hubačíková et al. 2020).

Land use changes have caused a significant change in the hydrological regime, having a significant impact on the runoff regime. The differences of some climatic characteristics in the urban environment are in Tab. 1.

Tab. 1. Comparison of climatic characteristics of urban environment and vicinity (Štecová et al. 2017).

\begin{tabular}{|l|l|l|}
\hline Climate characteristics & $\begin{array}{l}\text { Difference between city and } \\
\text { surroundings }\end{array}$ & Difference \\
\hline Air temperature & + & $0,5-3^{\circ} \mathrm{C}$ \\
\hline Overcast & + & $5-10 \%$ \\
\hline Total rainfall & + & $5-20 \%$ \\
\hline Rainwater runoff & + & $30-90 \%$ \\
\hline Incidence of mist & + & $30-100 \%$ \\
\hline Average air humidity & - & $20-60 \%$ \\
\hline Duration of snow cover & - & $2-18$ days \\
\hline Sunlight & - & $10-30 \%$ \\
\hline
\end{tabular}

In urbanized regions, the accumulative capacity of the area is reduced and water flows out without any benefit and contributes to flood situations. The share of urban greenery in individual regional cities in Slovakia is shown in Fig. 1.

The surface of an urbanized area consists largely of impermeable surfaces, which include roofs, roads, squares, parking areas and the like, which in some cases occupy more than $50 \%$ of the city's territory. Positive influence has grass areas and parks with the proportion of grasses, shrubs and trees, where the infiltration is significantly higher. This depends on the surface infiltration capacity. If there is accumulation of precipitation on the surface, the water may drain into the collectors or soak into the soil in the following time interval.

The basic relationship describing the water cycle in a country is the balance equation, which represents the relationship between precipitation, evapotranspiration, infiltration and water outflow from the territory. There are areas in urbanized areas that allow or prevent water infiltration into the surface. According to (Vitek 2008) the changes in hydrological regime depending on the level of urbanization are shown in the following Tab. 2.

This analysis shows that, compared to the natural landscape, in an intensive urbanized area, the outflow of water from the territory increases by up to $40 \%$.

An even more pronounced impact is reported by McCormack by presenting the water outflow relationships in Fig. 2. Where it assumes that rainwater runoff from urbanized areas can reach as much as $95 \%$ of the total rainfall.



Fig. 1. Share of urban greenery in regional capitals of the SR (Nitra 2012). 
Tab. 2. Rainwater cycle (\%) depending on urbanization of the territory (Vitek 2008; 2017).

\begin{tabular}{|l|c|c|c|c|c|}
\hline \multicolumn{2}{|l|}{ Surface } & Evaporation & $\begin{array}{l}\text { Surface } \\
\text { outfall }\end{array}$ & $\begin{array}{l}\text { Shallow } \\
\text { infiltration }\end{array}$ & $\begin{array}{l}\text { Deep } \\
\text { infiltration }\end{array}$ \\
\hline Natural & 40 & 10 & 25 & 25 \\
\hline \multirow{2}{*}{$\begin{array}{l}\text { Proportion } \\
\text { of impermeable } \\
\text { surfaces }\end{array}$} & $10-20 \%$ & 38 & 20 & 21 & 21 \\
\cline { 2 - 6 } & $35-50 \%$ & 35 & 30 & 20 & 15 \\
\hline
\end{tabular}

Open country

Agriculture

Sub-urban

Urban

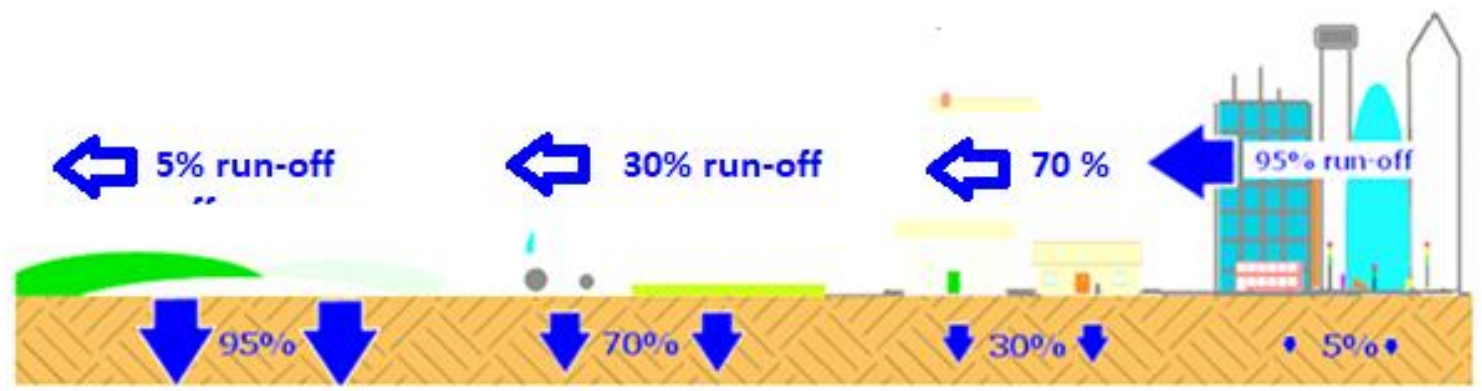

Fig. 2. Infiltration of precipitation into various surfaces (McCormack 2005).

\section{Materials and Methods}

To analyze the level of utilization of the urbanized area, it is possible to obtain information data from the land register, but qualitatively better by means of aerial and satellite images and maps obtained by satellite survey. Currently, there are a number of different image databases of satellite sensors (Sadiya 2015), such as LANDSAT, SPOT, MODIS, KOSMOS and others. It is also possible to use current orthophotomaps based on airborne images.

The extent of the areas in urbanized areas contributing to runoff can be identified by remote sensing images, in particular using multispectral images where surface properties can be distinguished by reflecting radiation in different spectral bands as well as different spectral indices such as LAI. At the same time, it is possible to identify areas that could be used to create space for rainwater infiltration and accumulation below the surface.

For this purpose, it is appropriate to use satellite images in different spectral bands, especially near infrared (NIR) and in the thermal band, where it is possible to distinguish individual surfaces by analyzing the training sets of each typical surface. Data obtained by different scanners in different spectral bands (Kotthaus et al. 2014) make it possible to identify different surfaces as documented (Moreira annd Galvão 2010) in Fig. 3.

The spectra of synthetic materials generally have a downward trend of reflection from NIR to SWIR (red lines). Mineral materials have a flat curve shape (green lines) or an upward trend (blue lines). Using these values and comparing them in different spectral bands it is possible to determine the character of individual surfaces. If multispectral images, thermal zone images and vegetation analysis using the NIR band are also added to the analysis, it is possible to categorize individual city surfaces and determine their share of the entire surface and consequently the potential for infiltration and runoff of annual rainfall in urbanized space.

From remote sensing (Shao et al. 2019) we can use images in the following spectral bands, Natural colors, false colors, NIR, SWIR and thermal band.

To analyze the changes in the extent of urbanization of the area of interest of the Slovak University of Agriculture in Nitra, we followed the dynamics of urbanization in 1950 and 1974, where 
Tátošová et al.

the state of the area is shown on the basis of aerial measurement images of the Topographic Institute in Banská Bystrica. The raster image was georeferenced and revised to quantify the extent of individual territories. The area of interest of SPU from 1950 and 1974 according to aerial photography is shown in Fig. 4.

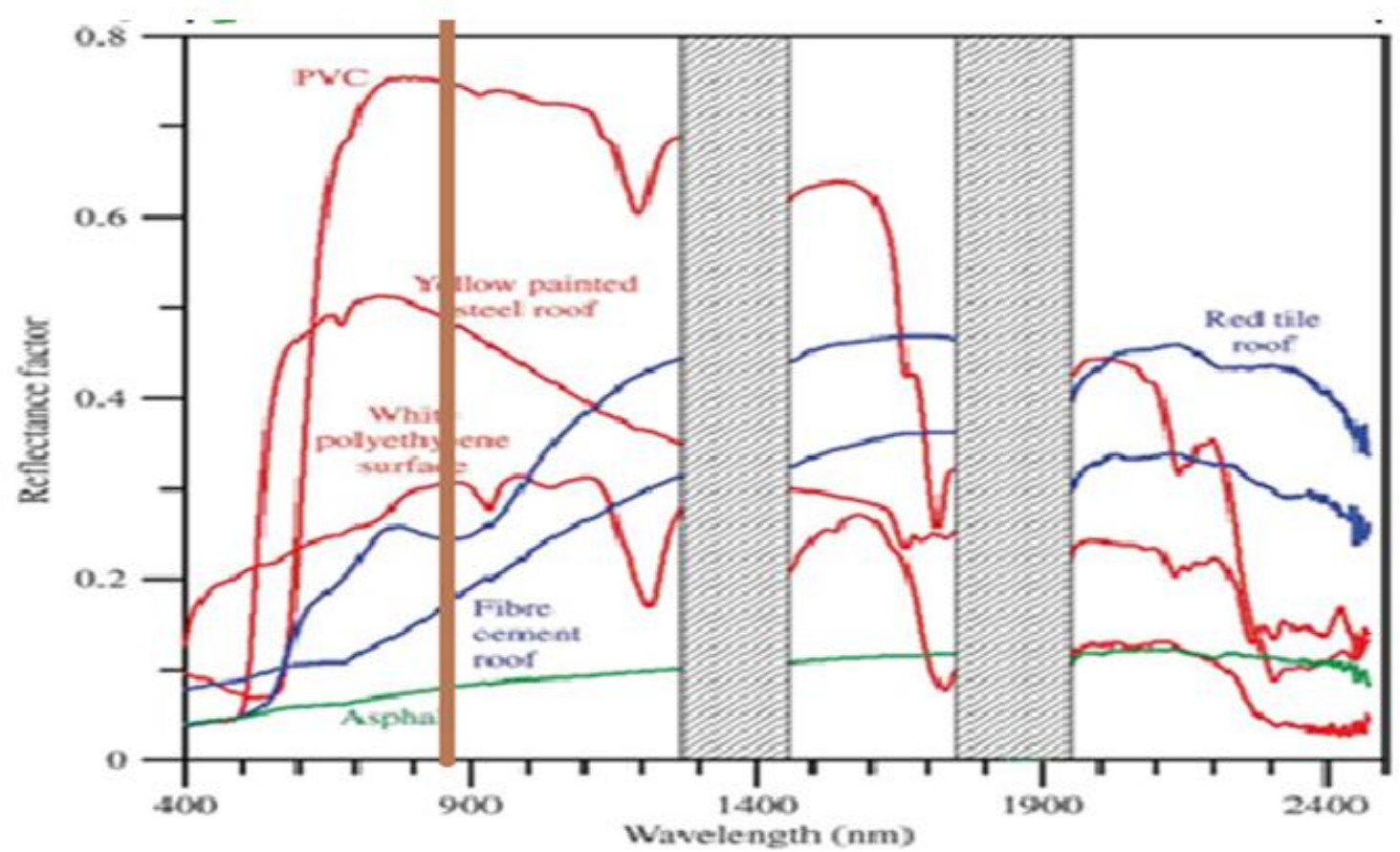

Fig. 3. Variation in spectra of different solid surface (Moreira annd Galvão 2010).
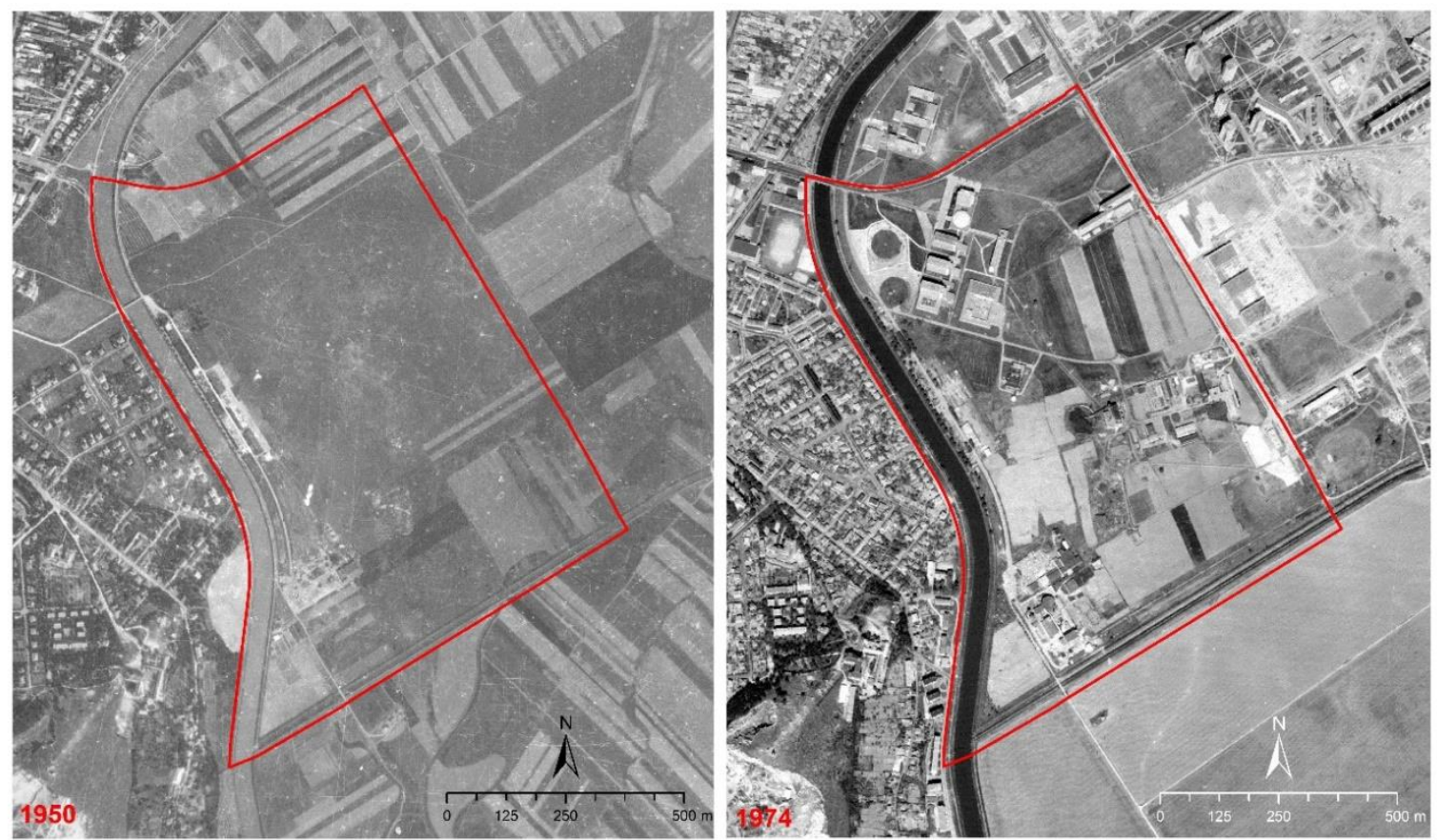

Fig. 4. Campus SAU in years 1950 and 1974 (Geodetic and Cartographic Institute Bratislava and National Forest Centre Zvolen 2017).

From the original, mainly agricultural land, the development of the area began, in which areas with significantly reduced infiltration capacity were created. Changes in the hydrological regime are reported by Arnold, and Gibbons, modified in Tab. 3. 
Tab. 3. Changes in hydrologic flows with increasing impervious surface in urbanizing catchments (Hashim et al. 2019).

\begin{tabular}{|c|c|c|c|c|}
\hline \multicolumn{5}{|c|}{ Changes in hydrologic flows } \\
\hline & Evapotranspiration & Shallow infiltration & Deep infiltration & Surface runoff \\
\hline $\begin{array}{l}\text { Without } \\
\text { urbanization }\end{array}$ & 40 & 25 & 25 & 10 \\
\hline $\begin{array}{l}\text { Urbanization } \\
12-20 \%\end{array}$ & 38 & 21 & 21 & 20 \\
\hline $\begin{array}{l}\text { Urbanization } \\
35-50 \%\end{array}$ & 35 & 20 & 15 & 30 \\
\hline $\begin{array}{l}\text { Urbanization } \\
75-100 \%\end{array}$ & 30 & 10 & 5 & 55 \\
\hline
\end{tabular}

The development of urbanization in the area of the area had a significant impact on the hydrological characteristics of the area and as a result the precipitation runoff increased. Comparison of changes in outflow and determination of its size is the subject of the submitted research.

The assessment of changes in the hydrological regime of the urbanized area in the long-term follow-up is based on changes in the use of urban areas. In terms of the water regime balance of the territory, the basic equation of water outflow from the territory, Formula (1) is used in the form:

$$
\mathrm{O}=\mathrm{P}-\mathrm{Et}+\mathrm{W} \quad(\mathrm{mm})
$$

$\begin{array}{ll}\mathrm{O} & \text { outflow } \\ \mathrm{P} & \text { precipitation } \\ \text { Et } & \text { evapotranspiration } \\ +-\mathrm{W} & \text { change of water supply in the territory }\end{array}$

From the point of view of water runoff, the character of the surface on which the rainfall falls is crucial. In the case of grassland and arable land, rainfall is retained and corresponding part of the rainfall is gradually infiltrated into the soil. In the case of solid surfaces, flat roofs, concrete and asphalt surfaces, more than $95 \%$ of the rainfall out-flows into surface systems (ditches, sewers, watercourses); wetting the surface, the part amount evaporating from the surface after the rain is over. The same is true for buildings with their roofs. Water falling to the water surface becomes an integral part of the water in the stream.

Images in different spectral bands (RGB and NIR), and in particular spectral indices derived therefrom, are preferably used to identify individual surfaces. Likewise, the intensity of thermal radiation can clearly distinguish different surfaces, especially vegetation, and surfaces of squares and roofs (Taubenböck et al. 2015; Rumor et al. 2007). In addition, the combination of a 3D city model with hyperspectral data makes it possible to obtain information about surface materials. In this way it is possible to identify and quantify roofing materials, types of asphalt, types of vegetation and condition, etc. However, these are data with spatial resolution over $1 \mathrm{~m}$ (Sadiya 2015).

Image classification by pixel identification is one of the most widely used remote data analysis for Earth observation applications. A number of methods are presented in the literature that can be categorized based on various criteria, such as object-based image classification, pixel object classification (Amini et al. 2018; Feng et al. 2020). 
Tátošová et al.

The NDVI index (Rumor et al. 2007) was used to determine the characteristics of the surfaces (Feng et al. 2020), using the "ANDES" software, where individual modules allow to determine the range of surfaces belonging to individual surfaces based on the number of pixels associated with each surface.

As a pilot area for the evaluation of changes we chose part of Nitra urban area from 1954-2017. Information is from aerial images and cadastral maps of the territory. Digital images from multispectral scanners that allow use of other software for evaluation of digital images are decisive (Fig. 5).

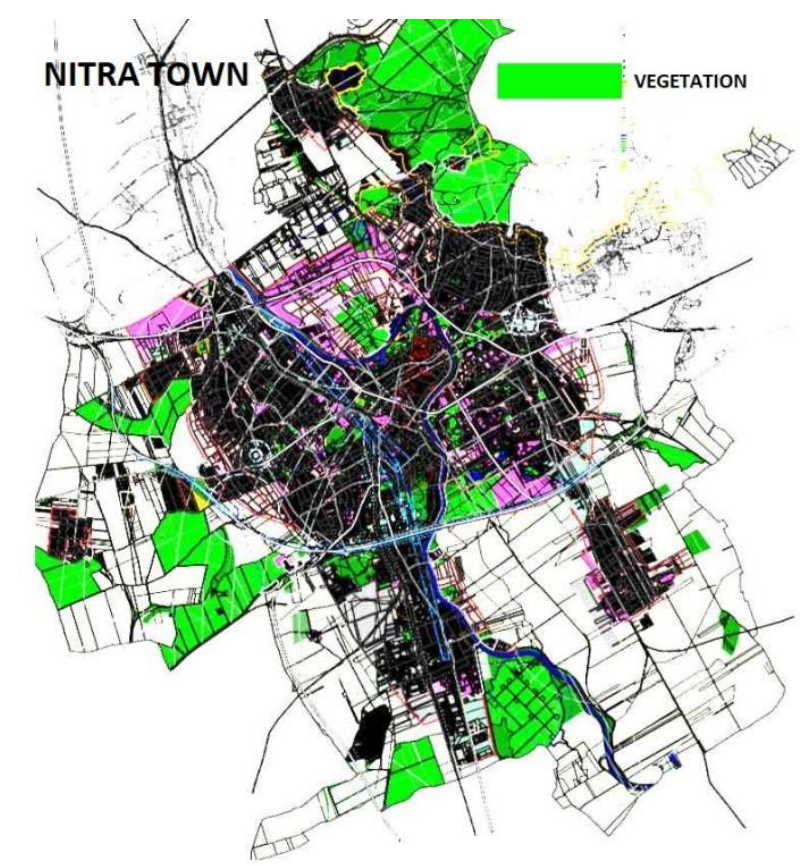

Fig. 5. Vegetation areas in the town of Nitra (Nitra, Territorial plan) [19].

In the monitored area of the city of Nitra (Town of Nitra 2020), in the older, central part, there is a relatively dense development, while in the new neighborhoods remains even greener (Fig. 6). The city is located in a temperate climate zone with an average annual temperature of $+9.7^{\circ} \mathrm{C}$. Annual rainfall is around $553 \mathrm{~mm}$ in diameter (SHMI).

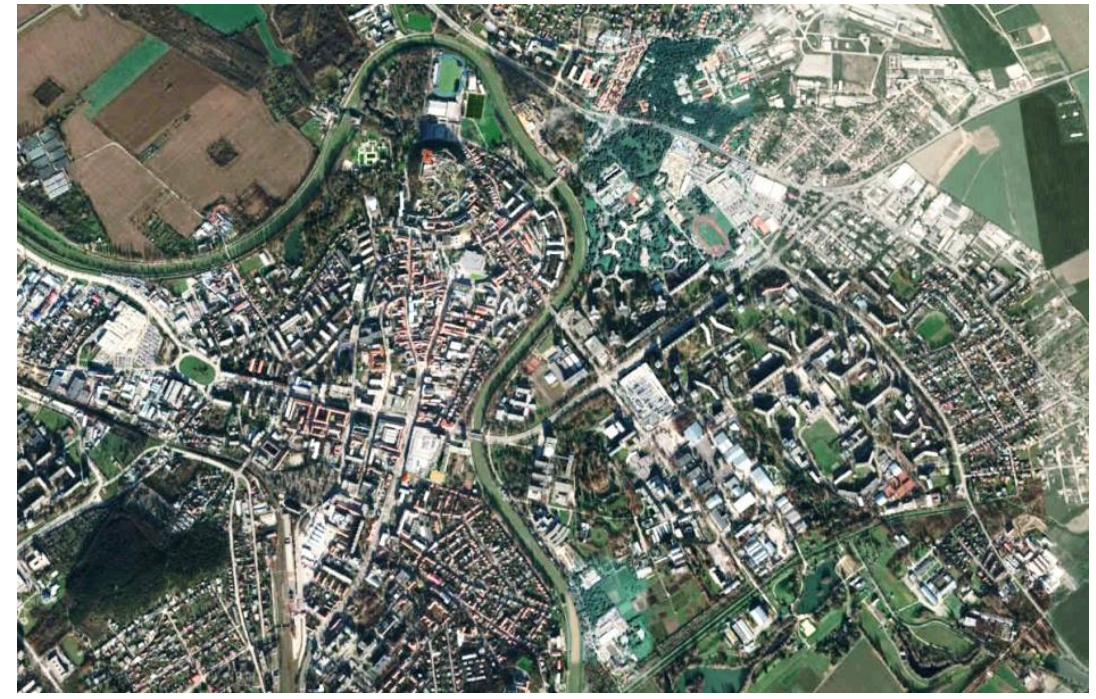

Fig. 6. City of Nitra, central part (Google Earth).

For the initial analysis of the current state of identification of the use of the territory of the SAU area, we used data from GCCA, GCI, NFC, TI. In the conditions of Slovakia there are good cadastral maps with identification of individual areas with different use (Fig. 7). 
Environment, Earth and Ecology Vol. 5 (2021), 26 - 38

Tátošová et al.

LEGEND:

$\square$ Campus SUA boundar

Land use by cadastre registry

Agricultural land

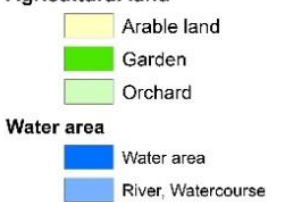

Built - up area

$$
\begin{array}{|l|l|}
\hline & \text { Court } \\
& \text { Buildings } \\
& \text { Roads, communications, parking } \\
\hline & \text { Protective wall }
\end{array}
$$

Other area

Fis. Functional greenery

Bushes, bound

$N$

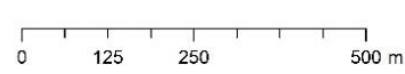

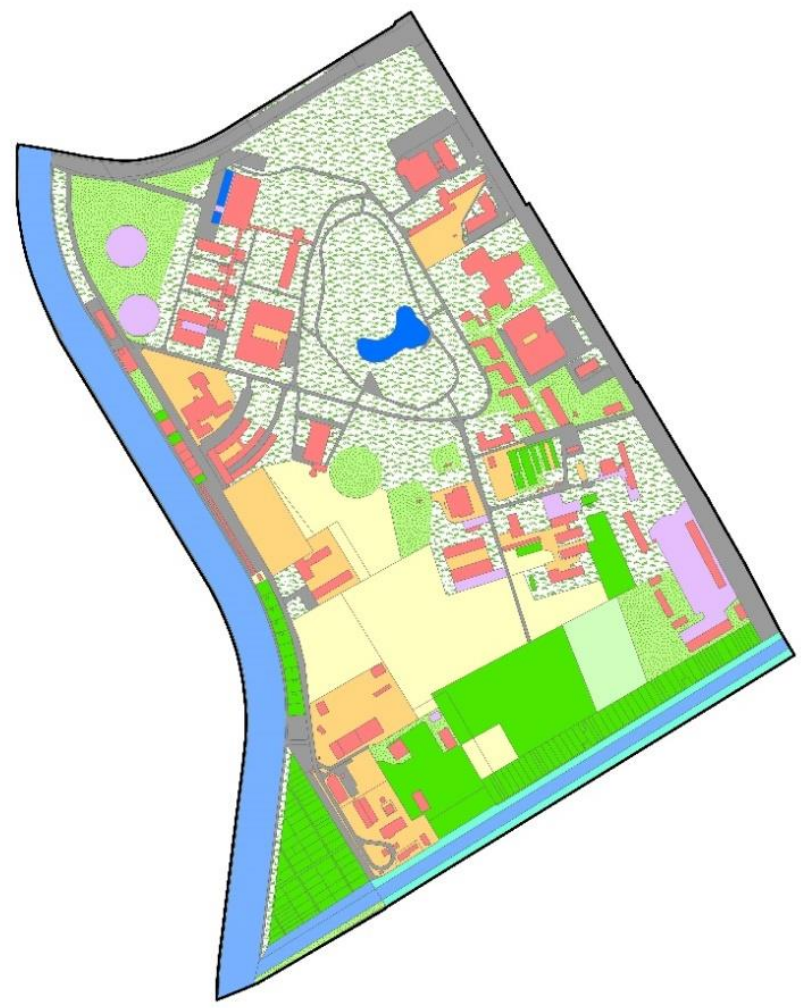

Fig. 7. Land use by cadaster registry 2017 [13].

In accordance with the focus of land use registered on the cadastral map of the territory, the representation of individual surfaces is shown in Tab. 4, 5, 6 and Fig. 8, Fig. 9.



LEGEND:
Campus SUA boundary

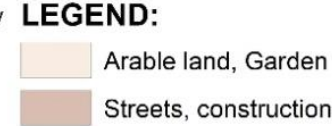

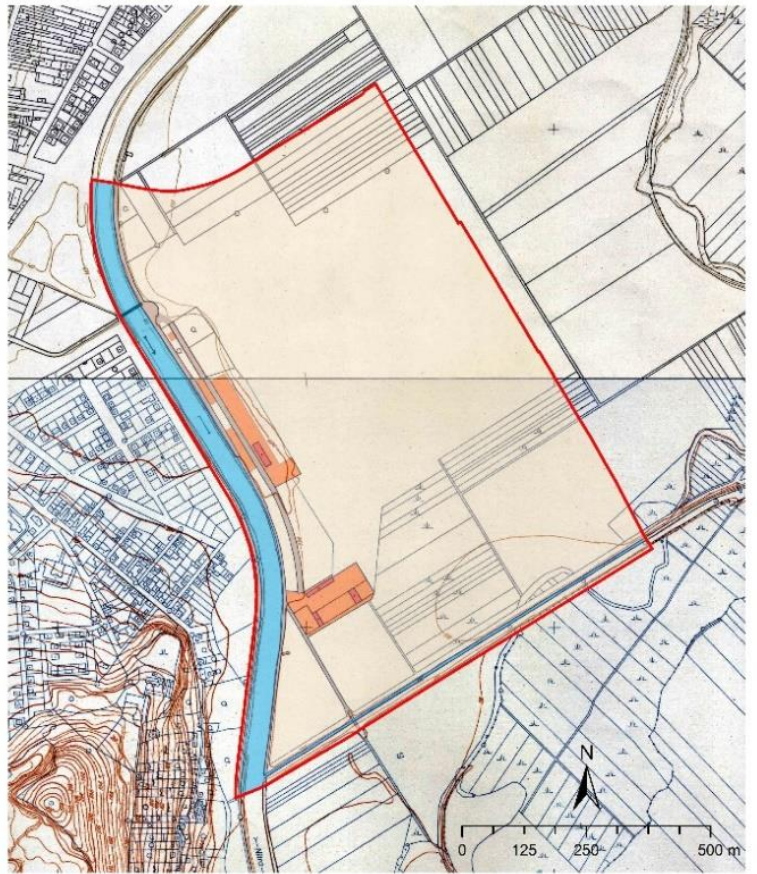

Buildings

Built - up areas

Water area

Fig. 8. Land use of the campus SAU in 1950 (Town of Nitra 2020). 
Environment, Earth and Ecology Vol. 5 (2021), 26 - 38

Tátošová et al.

Tab. 4. Land use by cadaster registry of the campus SAU (2017), average annual rainfall $553 \mathrm{~mm}$.

\begin{tabular}{|c|c|c|c|c|c|c|}
\hline \multirow{2}{*}{\multicolumn{2}{|c|}{ Use }} & $\begin{array}{l}\text { Area in } \\
\text { ha }\end{array}$ & $\begin{array}{l}\text { Area in } \\
\%\end{array}$ & $\begin{array}{l}\text { Runoff } \\
\text { coefficient }\end{array}$ & $\begin{array}{r}\text { Runoff } \\
\text { in } \mathrm{mm}\end{array}$ & $\begin{array}{l}\text { Water } \\
\text { volume }\end{array}$ \\
\hline & & 1 & 2 & 3 & 4 & $(1)^{*}(4)$ \\
\hline \multirow{3}{*}{$\begin{array}{l}\text { Agricultural } \\
\text { Land }\end{array}$} & Arable land & 7.51 & 9.13 & 0.05 & \multirow{3}{*}{27.65} & 207 \\
\hline & Garden & 8.90 & 10.81 & 0.05 & & 246 \\
\hline & Orchard & 1.16 & 1.41 & 0.05 & & 32 \\
\hline \multirow[t]{2}{*}{ Water area } & Water area & 0.50 & 0.60 & 1.0 & \multirow{2}{*}{533} & 266 \\
\hline & River, Watercourse & 8.77 & 10.66 & 1.0 & & 4,674 \\
\hline \multirow{5}{*}{$\begin{array}{l}\text { Built-up } \\
\text { areas, } \\
\text { courtyards, } \\
\text { roads }\end{array}$} & Court & 5.80 & 7.05 & 0.9 & \multirow{4}{*}{497.7} & 2,887 \\
\hline & Buildings & 6.86 & 8.34 & 0.9 & & 3,414 \\
\hline & $\begin{array}{l}\text { Roads, } \\
\text { communications }\end{array}$ & 11.46 & 13.92 & 0.9 & & 5,704 \\
\hline & Protective wall & 1.61 & 1.95 & 0.9 & & 801 \\
\hline & $\begin{array}{l}\text { Other Civil } \\
\text { engineering areas }\end{array}$ & 2.18 & 2.65 & 0.4 & 213.2 & 465 \\
\hline \multirow[t]{3}{*}{ Other areas } & Functional greenery & 20.80 & 25.28 & 0.05 & 27.65 & 575 \\
\hline & Bushes, bound & 6.74 & 8.19 & 0.4 & 213.2 & 1,437 \\
\hline & & 82.31 & 100.00 & $x$ & & 20,708 \\
\hline \multicolumn{2}{|c|}{ Percentage of urbanization } & $31.96 \%$ & & \multicolumn{2}{|l|}{$20,708 / 82.31$} & 251.6 \\
\hline
\end{tabular}

Weighted diameter of the outflow with respect to the size of the area pertaining to the specific land use is $251.6 \mathrm{~mm}$, which corresponds to the outflow coefficient from the SAU site 0.476. Based on the Table 3 outflow would be $30 \%$.

Tab. 5. Land use by military airborne photo of the campus SAU (1950), average annual rainfall $553 \mathrm{~mm}$.

\begin{tabular}{|l|l|l|l|l|l|}
\hline Use & $\begin{array}{l}\text { Area in } \\
\text { ha }\end{array}$ & $\begin{array}{l}\text { Area } \\
\text { in } \%\end{array}$ & $\begin{array}{l}\text { Outflow } \\
\text { coefficient }\end{array}$ & $\begin{array}{l}\text { Outflow } \\
(\mathrm{mm})\end{array}$ & $\begin{array}{l}\text { Water } \\
\text { volume }\end{array}$ \\
\hline & 1 & 2 & 3 & 4 & $(1)^{*}(4)$ \\
\hline Arable land, garden, & 70.93 & 86.17 & 0.05 & 27.65 & 1,961 \\
\hline Water area & 6.32 & 7.68 & 1.00 & 533 & 3,368 \\
\hline Streets, construction & 2.54 & 3.09 & 0.90 & 497.7 & 1,264 \\
\hline Built-up areas & 2.52 & 3.06 & 0,90 & 497.7 & 1,254 \\
\hline & 82.31 & 100.00 & $\mathrm{x}$ & & 7,847 \\
\hline & \multicolumn{7}{|l}{} \\
\hline \multicolumn{7}{|l|}{ Percentage of urbanization } & $6.15 \%$ & $7,847 / 82.31$ & 95.3 \\
\hline
\end{tabular}

Weighted diameter of the outflow with respect to the size of the area pertaining to the specific land use is $95.3 \mathrm{~mm}$, which corresponds to the outflow coefficient from the SAU site 0.17. Based on the Tab. 3 outflow would be $10 \%$.

Weighted diameter of the outflow with respect to the size of the area pertaining to the specific land use is $159.6 \mathrm{~mm}$, which corresponds to the outflow coefficient from the SAU site 0.30. Based on the Table 3 outflow would be $20 \%$. 
Environment, Earth and Ecology Vol. 5 (2021), 26 - 38

Tátošová et al.

Tab. 6. Land use by military airborne photo of the campus SAU (1974), average annual rainfall $553 \mathrm{~mm}$.

\begin{tabular}{|l|l|l|l|l|l|}
\hline Use & $\begin{array}{l}\text { Area } \\
\text { in ha }\end{array}$ & $\begin{array}{l}\text { Area } \\
\text { in \% }\end{array}$ & $\begin{array}{l}\text { Outflow } \\
\text { coefficient }\end{array}$ & $\begin{array}{l}\text { Outflow } \\
(\mathrm{mm})\end{array}$ & $\begin{array}{l}\text { Water } \\
\text { volume }\end{array}$ \\
\hline & 1 & 2 & 3 & 4 & $(1)^{*}(4)$ \\
\hline Arable land, garden, functional greenery & 59.68 & 72.5 & 0.05 & 27.65 & 1,650 \\
\hline Water area & 6.28 & 7.63 & 1.00 & 533 & 3,347 \\
\hline Roads, sidewalk, parking & 9.15 & 11.12 & 0.90 & 497.7 & 4,554 \\
\hline Built-up areas, building & 7.2 & 8.75 & 0.90 & 497.7 & 3,583 \\
\hline \multicolumn{7}{|l|}{} & 100.00 & $\mathrm{x}$ & & 13,134 \\
\hline \multicolumn{7}{|l|}{} \\
\hline \multicolumn{7}{|l|}{ Percentage of urbanization } & 82.31 & $19.86 \%$ & $13,134 / 82.31$ & 159.6 \\
\hline
\end{tabular}
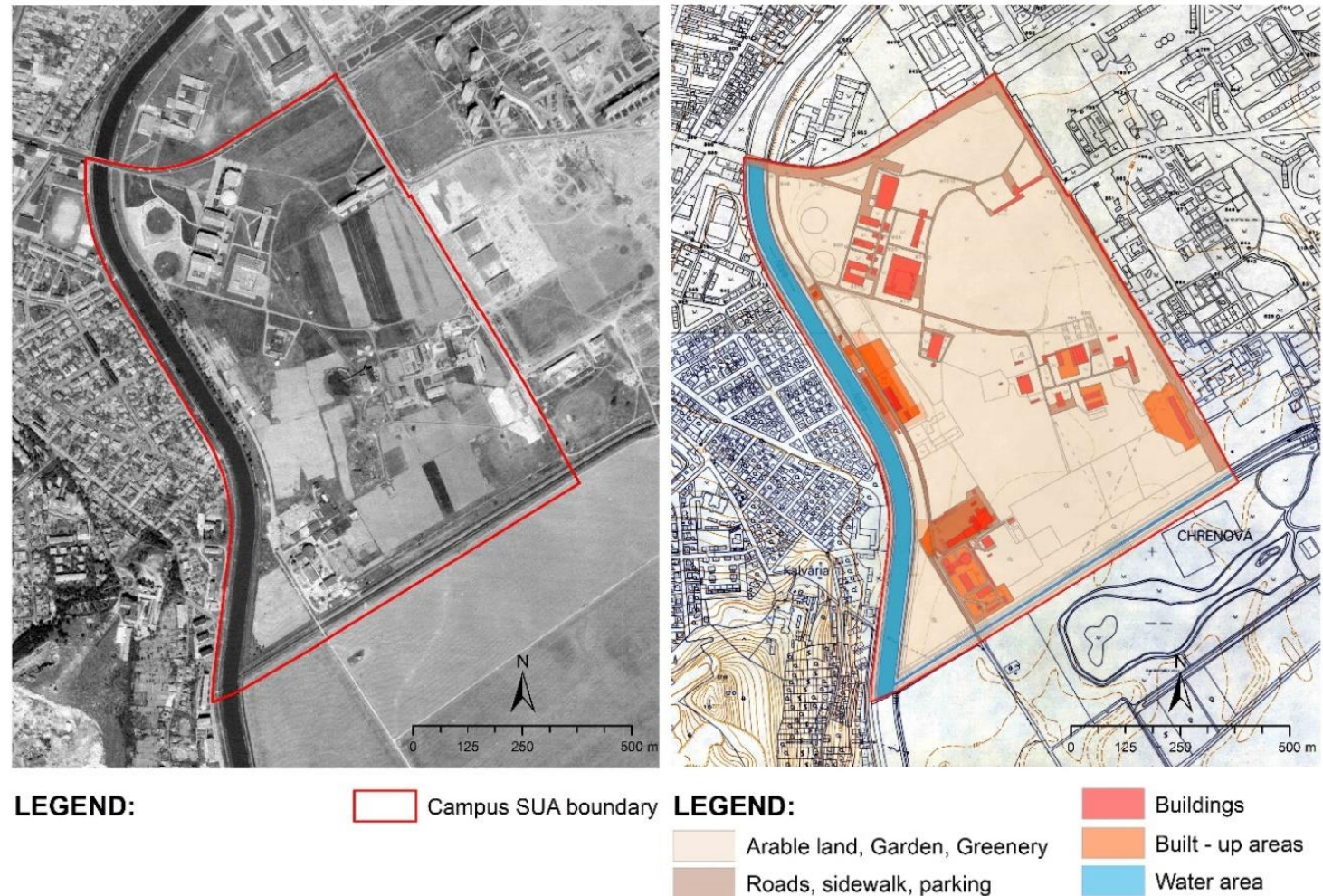

Fig. 9. Land use of the campus SAU in 1974 (Town of Nitra 2020).

We use orthophotomaps with appropriate resolution $(0.25 \mathrm{~m})$ to evaluate the current state of urbanization of the SAU territory. In the image, the area of interest is defined and the total number of pixels of that category is determined on the basis of the spectral bands R, G, B and NIR using the controlled classification, land use (Fig.10). Based on the number of pixels per category, their areal representation is determined. For further refinement the display of the modified image is used for NDVI identification. There is possibility of surface analysis based on identification of thermal characteristics of surfaces.

The experimental area, which mostly belongs to the Slovak University of Agriculture, is shown in Fig. 7 where the image is presented in RGB (TC) and FC display.

To identify the extent of the urbanized area and plots capable of infiltrating rainwater, we analyzed the image showing the NDVI spectral index. Through the reclassification of NDVI values, we distinguished two categories: permeable surfaces (with values from 0 to 1 ) and impermeable surfaces (with values from -1 to 0 ). The water surfaces due to their turbidity were taken from the RGB color composite by vectoring. The resulting categories are shown in Fig. 11. 

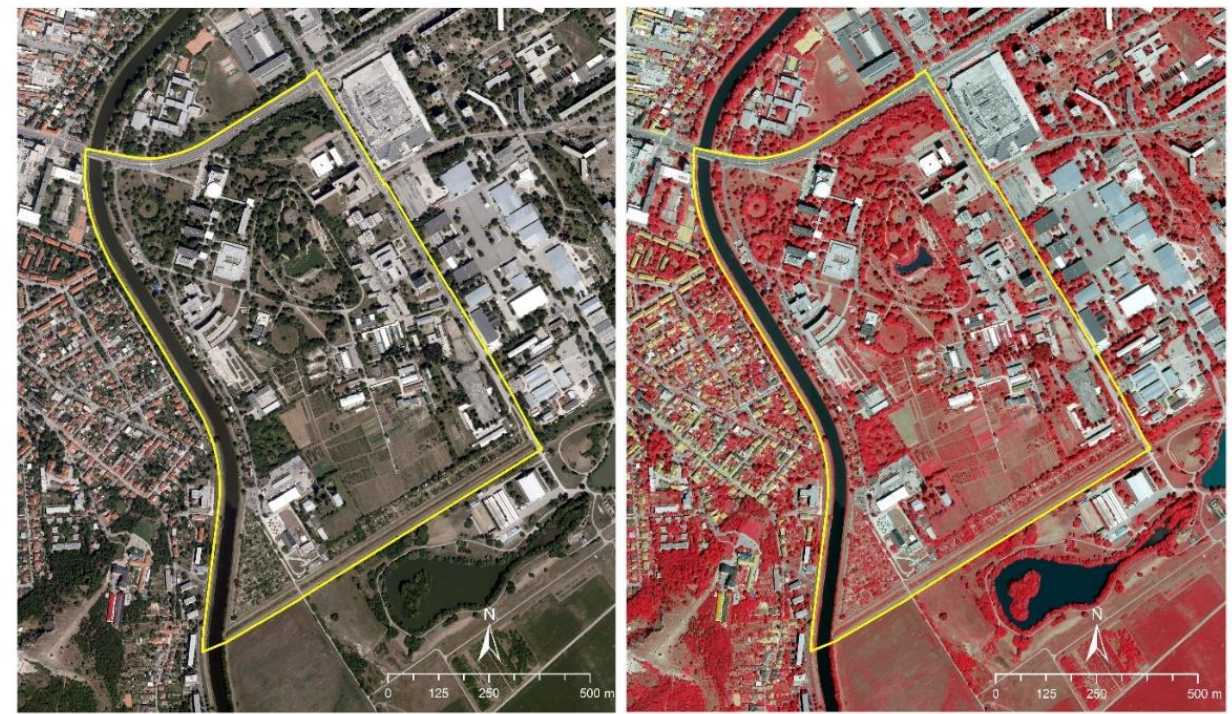

Fig. 10. Aerial images of SAU in RGB and FC views (C GKÚ, NLC; r.2017; (Town of Nitra 2020).
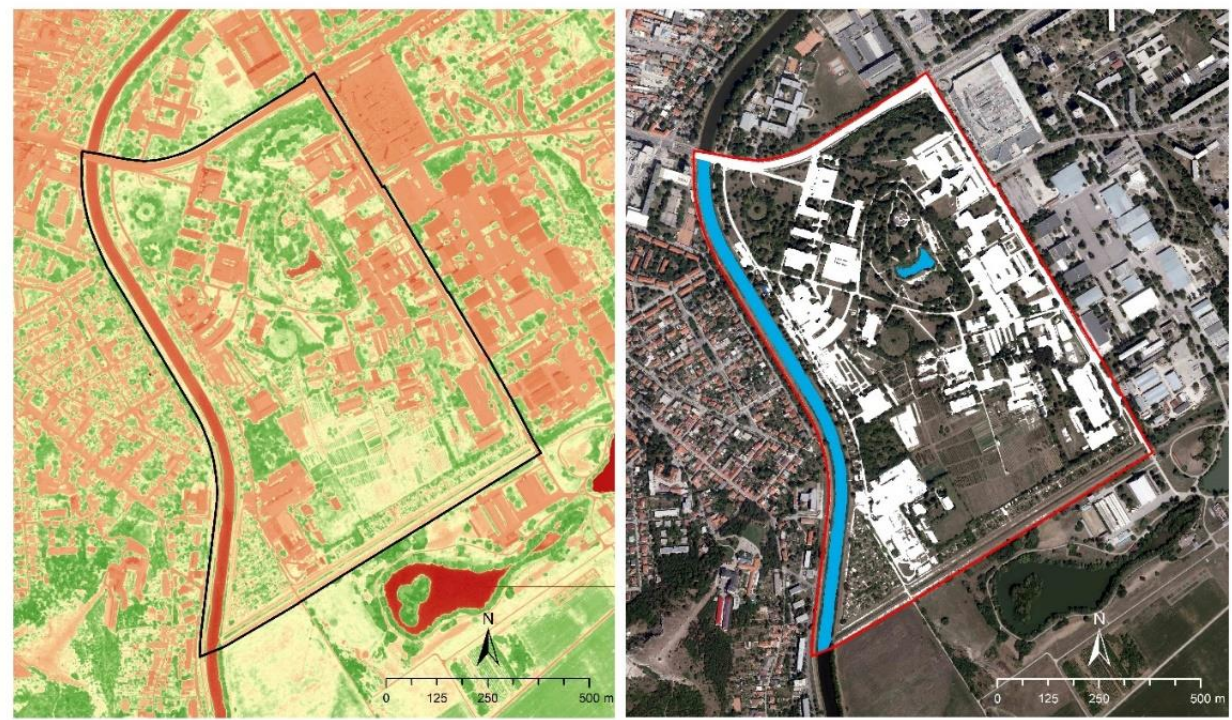

LEGEND:

NDVI value

LEGEND:

$\begin{array}{ll} & 0.70 \\ & -1.00\end{array}$

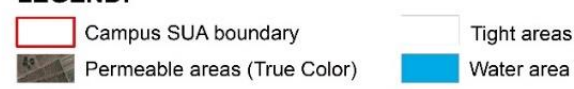

Fig. 11. Land use (NDVI value and reclass) of the campus SAU in 2017 (Geodetic and Cartographic Institute Bratislava and National Forest Centre Zvolen 2017).

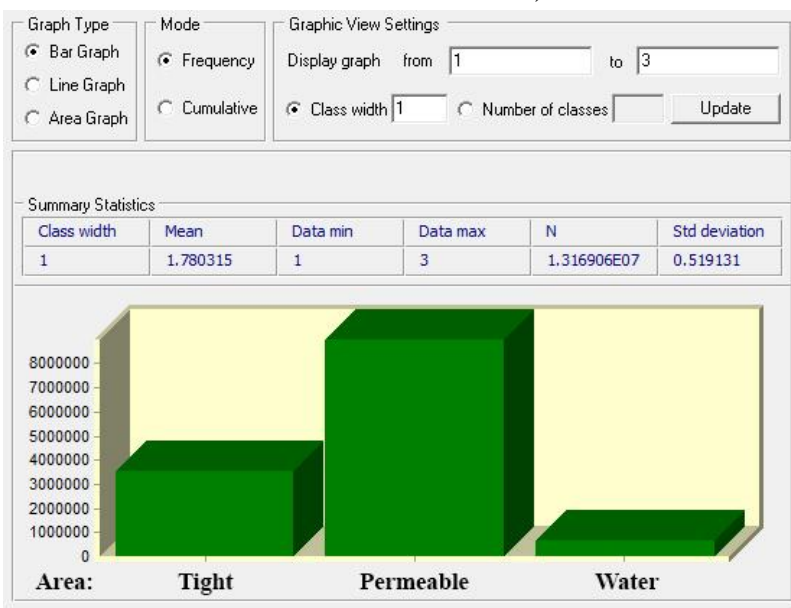

Fig. 12. Histogram based on the above reclassification of NDVI values. 
The histogram was created presenting the distribution of surfaces in dependence on the infiltration properties of the surfaces (Fig. 12).

\section{Results and Discussion}

\section{Research object}

To analyze the potential runoff water from the area of interest, we chose the Slovak University of Agriculture (SPU) campus, which is situated on the left bank of the Nitra River and is bounded by Andrej Hlinka Avenue, Academic Street and the Selenec Drainage Canal. In addition to buildings with flat roofs, there is a botanical garden, a production orchard, landscaping between pavilions, parking lots and roads. The water from the buildings is drained into the rainwater sewer and the Nitra River.

Rainfall falling on the grass surface is retained and gradually soaks into the soil. In the case of solid surfaces, concrete and asphalt surfaces, more than $95 \%$ of the rainfall flows to the surface (trenches, sewers, watercourses). Approximately $5 \%$ is calculated as so-called wetting the surface, the amount evaporating from the surface after the rain. The same is true for buildings, their roofs. Water falling to the water surface becomes an integral part of the water in the stream.

\section{Analysis of the area of interest}

In the monitored years 1950, 1974 and 2017 we made an analysis of land use and the gradual increase of the built-up area is described in Table 7.

We used spectral indices of NDVI derived from RGB NIR orthophotographs from the vegetation period of 2017, and aerial survey images of the Institute of Topography from 1950 and 1974, which we subsequently georeferenced and revised. For more accurate interpretation of surfaces from aerial photographs, we also used state maps derived from the archives of GKÚ Bratislava.

\section{Conclusions}

Intensive urbanization causes considerable problems in connection with the increased runoff from the territory. To determine the extent of urbanization affecting the hydrological mode, it is advantageous to use images obtained from scanners located on satellites, aircraft or other carriers (e.g. unmanned aircraft, so-called drones). Conventional images from traditional LANDSAT and SPOT scanners have a very low resolution and do not allow detailed processing of some data that better describes the surface properties. The orthophotographs used have a resolution of $0.25 \mathrm{~m}$, but only provide data in the RGB and NIR bands (Hashim et al. 2019; Lingfei et al. 2017).

It can be stated that the analysis of changes in surface properties in the area of interest showed that in the individual years part of the precipitation (average annual precipitation $\mathrm{mm}$ ), which flowed over the surface into the recipients gradually increased as shown in Tab. 7.

Tab. 7. Increase of water runoff from precipitation $(553 \mathrm{~mm})$ due to urbanization of the area.

\begin{tabular}{|l|l|l|l|}
\hline Year & $\begin{array}{l}\text { Urbanization } \\
\%\end{array}$ & $\begin{array}{l}\text { Infiltration } \\
\text { and evapotranspiration }(\mathrm{mm})\end{array}$ & $\begin{array}{l}\text { Rainwater runoff } \\
(\mathrm{mm})\end{array}$ \\
\hline 1950 & 6.15 & 437.7 & 95.3 \\
\hline 1974 & 19.86 & 373.4 & 159.6 \\
\hline 2017 & 31.96 & 281.4 & 251.6 \\
\hline
\end{tabular}

Improvements in the use and accumulation of rainwater could be achieved by expanding the infiltration areas by building green roofs and diverting rainfall accumulated on impermeable car park surfaces and roads into the seepage holes within existing greenery, even at the cost of flooding part of 
the parks with short-term artificial wetlands. In order to identify areas of rainfall accumulation, it is possible to use a digital terrain model Fig. 13 created by interpolation from LIDAR altimetry data, whose density is up to 33 points per $\mathrm{m}^{2}$.

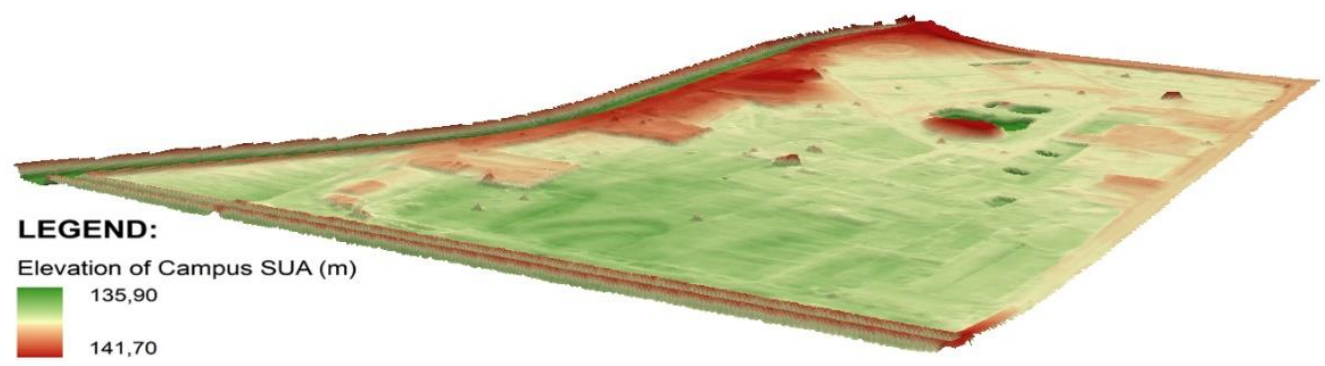

Fig. 13. Digital terrain model of Campus SAU (,Products feed ALS: GCCA SR“).

\section{Additional information:}

Author Contributions: Conceptualization, L.T., K.Š., B.N. and D.H.; methodology, L.T. and D.H.; investigation, L.T., K.Š., B.N. and D.H.; resources, B.N. and D.H.; data curation, K.Š.; writing-original draft preparation, L.T.; writing - review and editing, B.N. and K.Š..; visualization, K.Š.; supervision, D.H.; project administration, L.T.; funding acquisition L.T.. All authors have read and agreed to the published version of the manuscript.

Funding: This study was supported by the grant KEGA 027SPU-4/2020 3D Modeling and in Situ Technologies for Research, Teaching and Application in Remote Sensing, Photogrammetry and Geoinformation Systems Laboratory.

Acknowledgments: This publication is the result of the project implementation: „Scientific support of climate change adaptation in agriculture and mitigation of soil degradation" (ITMS2014+313011W580) supported by the Integrated Infrastructure Operational Programme funded by the ERDF. Thank to Geodetic and Cartographic Institute Bratislava and National Forest Centre Zvolen (C GKÚ, NLC; r.2017), „Products feed ALS: GCCA SR“, Topographic Institute Banská Bystrica for providing cadastral and digital images of the city of Nitra, on the basis of which we were able to carry out the submitted analysis.

\section{References}

Amini S, Homayouni S, Safari A, Darvishsefat A (2018) Automatische Erkennung von Oberflächenmaterialien städtischer Objectekte. Geo-spatial Information Science, Volume 21 - Issue 2.

Antal J, Igaz D (2018) Aplikovaná agrohydrológia. 8. vyd. Nitra: Slovenská pol’nohospodárska univerzita, 210.

Feng L, Han L, Liujun Z, Huang Y, Song G (2020) Urban vegetation mapping based on the hj-1 NDVI reconstruction. Remote Sensing and Spatial Information Sciences, Volume XLI-B8, 2016.

Hashim H, Zulkiflee AL, Adnan N (2019) Urban vegetation classification with NDVI threshold value method with very high resolution (VHR) pleiades imagery. Remote sensing and spatial information sciences, volume xlii-4/w16.

Hubačíková V, Pokrývková J, Marková J (2020) Change of hydrological regime and water quality due to reduced wastewater discharged into surface waters. In Polish Journal of Environmental Studies. vol. 29 , no. 4, s. 2661-2668, 2020.

Kotthaus S, Smith TEL, Wooster MJ, Grimmond CSB (2014) Derivation of an urban materials spectral library through emittanceand reflectance spectroscopy. ISPRS Journal of Photogrametry and remote sensing 94, 194-2012.

Lingfei S, Feng L, Yong G, Giles MF, Li X, Wang L, Zhang Y, Yun D (2017) Impervious Surface Change Mapping with an Uncertainty-Based Spatial-Temporal Consistency. Model: A Case Study 
Tátošová et al.

in Wuhan City Using Landsat Time-Series Datasets from 1987 to 2016. Remote. Sens. 9(11): 1148. Available from: https://www.mdpi.com/2072-4292/9/11/1148 [cited 2021 February 16].

McCormack Tony (2005) Available from: http://www.pavingexpert.com/ [cited 2021 March 2].

Moreira RC, Galvão LS (2010) Variation in spectral shape of urban materials. Remote Sensing Letters, $1: 3,149-158$.

Nitra (2012) Territorial plan. Available from: http://www.uzemneplany.sk/upn/nitra/ [cited 2021 March 2].

Rumor M, Coors V, Fendel EM, Zlatanova S (2007) Urban and Regional Data Management, Chap. Integrating Urban GIS, CAD and BIM Data By Service-Based Virtual 3D City Models, Taylor \& Francis Group, London, UK, 2008; pp. 381-393.

Sadiya TB (2015) Comparison and Analysis of the Pixel-based and Object-Oriented Methods for Land Cover Classification with ETM+ Data.

Shao Z, Fu H, Li D, Altan O, Cheng T (2019) Remote sensing monitoring of multi-scale watersheds impermeability for urban hydrological evaluation, Remote Sensing of Environment, Volume 232, 111338 October 2019, ISSN 0034-4257, Available from:

https://doi.org/10.1016/j.rse.2019.111338 [cited 2021 March 2].

Spatial data from: Geodetic and Cartographic Institute Bratislava and National Forest Centre Zvolen (2017) „Products feed ALS: GCCA SR“, Topographic Institute Banská Bystrica. C GKÚ, NLC.

STN EN 16941-1 (2018) On-site non-potable water systems. Part 1: Systems for the use of rainwater, 2018.

Štecová I, Baštáková V, Kluvánková T (2017) Zelená adaptácii klímy v mestskom prostredí. Ecosystem Services and Climate Change Adaptation in urban Areas. Životné prostredie, 51, 4, p. $240-243$.

Taubenböck H, Wurm M, Esch T, Dech S (2015) Globale Urbanisierung. Springer Verlag.

Town of Nitra (2020) Available from: https://sk.wikipedia.org/wiki/Nitra [cited 2021 February 6].

Vitek J (2008) Odvodňování urbanizovaných území podle principú udržitelného rozvoje. Urbanismus a územní rozvoj, XI, 4/2008.

Vitek J (2017) Modrozelená infrastruktura: naděje pro řeky, naděje pro člověka. In. Vodní nádrže 2017. Konferencie vodní nádrže, Available from: http://vodninadrze.pmo.cz/ [cited 2021 January 11]. 